\title{
DOI https://doi.org/10.30525/978-9934-26-116-9-50
}

\section{КЛАСИФІКАЦІЯ МІЖНАРОДНИХ ДОГОВОРІВ УКРАЇНИ ПРО РЕАДМІСІЮ ОСІБ}

\author{
Науменко Н. М. \\ перший заступник Голови Державної міграџійної служби України \\ м. Київ, Украӥна
}

Наразі Україна на підставі відповідних міжнародних договорів врегулювала питання реадмісії осіб з 37 державами світу. Зазначені договори можна класифікувати за декількома основними критеріями.

Перший критерій - це наявність спільного кордону між Україною та іншою державою - стороною договору про реадмісію.

За цим критерієм можна виділити 2 види договорів:

а) договори про реадмісію 3 державами, 3 якими Україна має спільний державний кордон, - у цьому зв'язку доречно підкреслити, що Україна має договори про реадмісію з усіма сусідніми 3 нею державами, зокрема, це: Республіка Польща, Словацька Республіка, Угорська Республіка, Румунія [1], Республіка Молдова [2], Республіка Білорусь [3] та Російська Федерація [4]; i

б) договори про реадмісію $з$ державами, з якими Україна не має спільного державного кордону: Грузія [5], Ісландія [6], Королівство Данія [7], Королівство Норвегія [8], Соціалістична Республіка В'єтнам [9], Турецька Республіка [10], Туркменістан [11] і Швейцарська Конфедерація [12;13].

Другий критерій - це суб'єктний склад договору про реадмісію за участю України.

Цей критерій також дозволяє виділити 2 види договорів:

а) практично усі договори України про реадмісію осіб є двосторонніми міжнародними договорами з іншими державами;

б) виключення складає лише Угода про реадмісію між Україною та Європейським Співтовариством 2007 р. [1]; зауважимо, що 31 грудня 2009 р. Свропейське Співтовариство припинило свою діяльність, а його правонаступником став Свропейський Союз [14], правова природа якого найбільш близька до міжнародної міжурядової організації. Угода про реадмісію між Україною та Європейським Співтовариством 2007 р. [1] також має двосторонній характер, але при цьому охоплює найбільшу кількість держав, 3 якими Україна врегулювала відносини реадмісії осіб, оскільки зазначена Угода поширюється на всіх держав членів Свропейського Союзу, за винятком Данії, з якою Україна уклала окрему угоду про реадмісію $[7 ; 15]$. 
Третій критерій - рівень укладення договору про реадмісію.

За цим критерієм так само можна виділити 2 види договорів:

а) переважна більшість договорів України про реадмісію укладаються на рівні урядів договірних сторін [2, 4-12];

б) разом 3 тим деякі договори про реадмісію укладаються на найвищому - міждержавному рівні, зокрема, це договори: 3 Європейським Союзом [1], з Республікою Білорусь [3] і з Швейцарською Конфедерацією [13].

Однак обидва зазначені види міжнародних договорів мають однакову юридичну силу, оскільки проходять однакову процедуру ратифікації Верховною Радою України, як це передбачено пунктом б) частини другої статті 9 Закону України «Про міжнародні договори України» від 29.06.2004 p. № 1906-IV (ратифікації підлягають міжнародні договори України ... що стосуються прав, свобод та обов'язків людини ... ) [16, ст. 9].

Четвертий критерій - це ступінь правового регулювання за договором про реадмісію.

За цим критерієм можна виділити 2 види договорів:

a) власне договори про реадмісію та

б) імплементаційні (виконавчі) протоколи до договорів про реадмісію.

Різниця між ними полягає в тому, що деякі міжнародні договори про реадмісію можуть містити занадто загальні положення, для реалізації яких потрібно застосовувати більш детальні правові інструменти імплементаційні протоколи. Імплементаційні протоколи не $\epsilon$ самостійними міжнародно-правовими договорами, оскільки вони органічно пов'язані з положеннями інших, основних по відношенню до них, чинних міжнародних договорів про реадмісію осіб, і є невід'ємною частиною таких договорів [17, с. 113].

Наразі Україна уклала імплементаційні протоколи з Республікою Польщею, Естонською Республікою, Литовською Республікою, Республікою Австрією, Чеською Республікою [18], Грузією, Республікою Молдовою та Російською Федерацією.

За результатами дослідження можна зробити висновок, що міжнародні договори України про реадмісію осіб можна класифікувати за 4 основними критеріями:

1) наявність спільного кордону між Україною та іншою державою стороною договору про реадмісію;

2) суб'єктний склад договору про реадмісію;

3) рівень укладення договору про реадмісію;

4) ступінь правового регулювання за договором про реадмісію. 


\section{Література:}

1. Agreement between the European Community and Ukraine on the readmission of persons. Luxembourg, 18 June 2007. OJ L 332, 18.12.2007, P. 48-65. URL: https://eur-lex.europa.eu/legal-content/EN/TXT/?uri= uriserv:OJ.L_.2007.332.01.0046.01.ENG (дата звернення: 05.07.2021).

2. Угода про реадмісію осіб між Кабінетом Міністрів України та Урядом Республіки Молдова. Вчинено в м. Кишинів 06.10.2017 p. URL: https://zakon.rada.gov.ua/laws/show/498_006-17\#Text (дата звернення: 05.07.2021).

3. Угода між Україною та Республікою Білорусь про реадмісію. Вчинено в м. Гомель 26.10.2018 p. URL: https://zakon.rada.gov.ua/laws/ show/112_003-18\#Text (дата звернення: 05.07.2021).

4. Угода між Кабінетом Міністрів України та Урядом Російської Федерації про реадмісію. Вчинено в м. Москва 22.10.2012 . URL: https://zakon.rada.gov.ua/laws/show/643_419\#Text (дата звернення: 05.07.2021).

5. Угода між Кабінетом Міністрів України і Виконавчою владою Грузії про приймання і передачу осіб (реадмісію), які знаходяться на територіях держав незаконно: Вчинено в м. Київ 22.04.2003 p. URL: https://zakon.rada.gov.ua/laws/show/268_050\#Text (дата звернення: 05.07.2021).

6. Угода між Кабінетом Міністрів України та Урядом Ісландії про реадмісію осіб. Вчинено в м. Нью-Йорк 25.09.2013 p. URL: https://zakon.rada.gov.ua/laws/show/352_004\#Text (дата звернення: 05.07.2021).

7. Угода між Кабінетом Міністрів України і Урядом Королівства Данія про реадмісію осіб. Учинена в м. Копенгаген 16.03.2007 p. URL: https://zakon.rada.gov.ua/laws/show/208_017\#Text (дата звернення: 05.07.2021).

8. Угода про реадмісію осіб між Кабінетом Міністрів України та Урядом Королівства Норвегія. Вчинено в м. Осло 13.02.2008 p. URL: https://zakon.rada.gov.ua/laws/show/578_019\#Tеxt (дата звернення: 05.07.2021).

9. Угода між Кабінетом Міністрів України та Урядом Соціалістичної Республіки В'єтнам про реадмісію громадян обох держав. Вчинено в м. Нью-Йорк 25.09.2007 p. URL: https://zakon.rada.gov.ua/ laws/show/704_029\#Text (дата звернення: 05.07.2021).

10. Угода між Кабінетом Міністрів України та Урядом Турецької Республіки про реадмісію осіб. Вчинено в м. Анкара 07.06.2005 p. URL: https://zakon.rada.gov.ua/laws/show/792_053\#Text (дата звернення: 05.07.2021). 
11. Угода між Кабінетом Міністрів України та Урядом Туркменістану про реадмісію осіб. Вчинено в м. Києві 14.05.2001 p. URL: https://zakon.rada.gov.ua/laws/show/795_703\%20(\#Text (дата звернення: 05.07.2021).

12. Угода між Кабінетом Міністрів України та Швейцарською Федеральною Радою про реадмісію осіб, які перебувають на територіях ї держав нелегально. Вчинено у м. Києві 11.07.2003 p. URL: https://zakon.rada.gov.ua/laws/show/756_022\#Text (дата звернення: 05.07.2021).

13. Угода між Україною та Швейцарською Конфедерацією про реадмісію осіб. Учинено в м. Київ 07.06.2017 p. URL: https://zakon.rada.gov.ua/laws/show/756_001-17\#Text (дата звернення: 05.07.2021).

14. Treaty of Lisbon amending the Treaty on European Union and the Treaty establishing the European Community, signed at Lisbon, 13 December 2007. OJ C 306, 17.12.2007, P. 1-271. URL: https://eurlex.europa.eu/legal-content/EN/TXT/PDF/?uri=OJ:C:2007:306:FULL\&from $=\mathrm{EN}$ (дата звернення: 05.07.2021).

15. Naumenko N. Peculiarities of Agreement between Ukraine and Denmark on the readmission of persons. Recht der Osteuropäischen Staaten. 2019. № 1. P. 123-127. URL: https://www.uni-goettingen.de/de/document/ download/ca207b2c626da0c3a651dab3e413069e.pdf/ReOS\%2001\%20aus\% 202019.pdf (дата звернення: 05.07.2021).

16. Про міжнародні договори України: Закон України від 29.06.2004 p. № 1906-IV. URL: https://zakon.rada.gov.ua/laws/show/190615\#Техt (дата звернення: 05.07.2021).

17. Олійник С. М. Міжнародно-правове регулювання реадмісії осіб: дис. ... канд. юрид. наук. Київ, 2019. 216 с.

18. Naumenko N. Legal nature of the implementing protocols to the EURAs (in the case of Ukraine). Visegrad Journal on Human Rights. 2020. Iss. 6. Vol. 1. P. 297-302. URL: http://vjhr-journal.sk/wpcontent/uploads/2021/02/VVHR-6-1-2020.pdf (дата звернення: 05.07.2021). 